\title{
Developments in Academic Geography and its Relationship with Geographical Education - The Case of Southeast Asia
}

\author{
Chew-Hung CHANG'1 \\ Nanyang Technological University \\ SINGAPORE
}

\author{
Shyam Anand SINGH ${ }^{2}$ \\ Nanyang Technological University \\ SINGAPORE
}

\begin{abstract}
${ }^{1}$ Corresponding author: Dr. Chew-Hung Chang, National Institute of Education, Nanyang Technological University, Singapore. chewhung.chang [at]nie.edu.sg. ORCID: 0000-0002-1301-2735

2Mr. Shyam Anand Singh, National Institute of Education, Nanyang Technological University, Singapore. shyam.singh[at]nie.edu.sg. ORCID: 0000-0001-8435-9501
\end{abstract}

\begin{abstract}
For over 30 years, the Southeast Asian Geography Association (SEAGA) has provided a dynamic platform for the exchange of knowledge, research findings, and ideas among academics, policymakers, and educators from Southeast Asia and those working on Southeast Asia. Using Marsden's (1989) notion of the politicization of geography by significant power groups, this article describes a critical narrative of the key trends, themes, and topics defining scholarly discourse in the community of SEAGA and its potential impact on school geography in the region. For each of the three decades (1990-1999, 2000-2009, and 2010-2019), the authors analyzed significant themes and issues for each period. Employing purposive sampling of conference proceedings and topics presented between 1990 and 2017, the authors found the following trends over the years: i) the pluralization and diversification of themes and topics; ii) an increasing interest for cross-thematic studies, and iii) a greater emphasis on sustainability and environmental issues in recent years. Based on these observations, the authors acknowledge that the evolution of discourses in SEAGA conferences is also a part of broader thematic shifts in international publications such as the Journal of Geography and has a direct bearing on changes in the geography curriculum in schools in other places around the world. In addition, there is a natural confluence of academic geographers and geography educators in the region in discoursing topics that matter to Southeast Asia.250 words maximum.
\end{abstract}

\section{Keywords}

Geography curriculum, Southeast Asia, Politicization, Developments in Academic Geography 
A geography curriculum is not just a planned sequence of work that guides instruction, but it is "a complex social and political construction built on understandings of different groups in society (including teachers) based on the past and present and with an imagination for the future" (Goodson, 1988). Indeed, the discourses in the subject discipline of Geography will have an indelible impact on the development of geographical education. At the very least, the epistemic community of geographers will have its influence through the "choice of content and definitions of social purpose" (Marsden, 1989), especially if they are in any way involved in the school geography curriculum development process.

Since its establishment in 1990, the Southeast Asian Geography Association (SEAGA) has provided a dynamic platform for the exchange of knowledge, information, research findings, and ideas amongst scholars, researchers, policymakers, and educators from Southeast Asia and beyond (Ooi \& Goh, 2008, p. 292). Given the colonial history of most nations in the region, the production of knowledge in each of the new nation-states in Southeast Asia has been mounded by the knowledge frame and epistemology of their previous colonizers (Shamsul, 2007, p. 119). As such, the challenge of nation-building has, at times, been exacerbated by the insufficient modes of knowledge production that could effectively deliver solutions appropriate to local contexts (Taiwo, 1993, p. 891). To this effect, SEAGA has been instrumental in cultivating knowledge that centers Southeast Asian perspectives, issues, and narratives in a largely developing region, through biennial conferences organized in different parts of the region. Approximately every two years, more than 150 participants from the region and around the world meet to discuss and exchange ideas on a wide range of topics (Ooi \& Goh, 2008, p. 295).

In the past three decades, while SEAGA conferences have mostly focused on issues of development, sustainability, and globalization, it has also covered themes affecting the region at the time. Prominent themes have included agricultural development, livelihoods threatened by change, rural poverty, the development of teaching and learning methods in Geography education, the skills and values that Geography contributes to life-long education as well as issues pertaining to identities and cultures such as the impact of development on minorities, and conflicts experienced by ethnic groups who move between borders (Ooi \& Goh, 2008, p. 296; Woube, 1999). While there is interaction among academic geographers and geography educators at the conferences, SEAGA has also addressed concerns of geographical research and geography education, as well as real-world issues affecting the region (Ooi \& Goh, 2008, p. 296), as evident from its conference proceedings, which over the years, have been directly or indirectly shaped by critical events affecting the region and beyond. The 1992 Rio de Janeiro Earth Summit and the Kyoto Protocol signed in 1997, for instance, brought environmental concerns such as sustainable development and climate change as critical considerations within the broader discourse of economic growth and social equity in the 1990s. Moreover, the economic reforms following the Asian Financial Crisis of 1997 and the impacts of globalization led to a greater focus on issues concerning economic development, urbanization, and tourism in SEAGA conferences in the 2000s. The occurrence of the Indian Ocean Tsunami in 2004 and the introduction of a panel on "living with natural hazards" at the 2006 SEAGA conference could not have been 
merely due to serendipity. More recently, the landmark Paris Agreement in 2015 to curb greenhouse gas emissions has led to an increased emphasis on sustainable development and climate change issues in SEAGA conferences as evidenced by the themes of the 2017 and the upcoming 2021 SEAGA conference.

While we are not describing a direct relationship between global and regional events and the themes of conference proceedings organized by SEAGA, we acknowledge the presence of mediating factors that might have influenced the dominance of specific themes following key events. In this regard, we seek to employ Marsden's (1989) notion of the politicization of geography by significant power groups to examine the key trends, themes, and topics defining scholarly discourse in the realm of Southeast Asian Geography, and its relationship with school geography. Examining each of the three decades (1990-1999, 2000-2009, and 20102019), we highlight significant themes and issues that have shaped each period. Moreover, by analyzing conference proceedings and topics presented between 1990 and 2017, the following trends have been seen over the years: i) the pluralization and diversification of themes and topics; ii) an increasing interest for cross-thematic studies, and iii) a greater emphasis on sustainable development and climate change issues in recent years.

\section{Methods}

A purposive sampling of conference topics from 1990, 1996, 1998, 2004, 2006, $2008,2010,2012,2014$, and $2017^{1}$ was conducted. Using the conference programs from books, archival and electronic records, the authors identified the key topics from presentations and the special panels from these years. The titles of presentations and special panels were recorded in an excel document and a word counter software was used to aggregate recurring concepts and terms for each year. It is regrettable that material from the 1992, 1994, and 2001 conferences was not archived. The results showed the keyword density ${ }^{2}$ of significant terms and concepts in the form of one, two, and three words. This preliminary data was further analyzed and terms that were mentioned less than three times in a year without a recurrence in subsequent years were excluded from the preliminary data set. The authors also excluded terms that had little relevance to geography (for example, words such as "case" and "study"). However, the software double-counted keywords that repeated themselves in phrases (for example, the term "development" is also counted along with the term "sustainable development" leading to a double count). To prevent double counting, the authors deducted the number of times a word exists as a two-word term from its appearance as a single term. ${ }^{3}$ In addition, precise terms

\footnotetext{
1 While all effort was made to retrieve documents from all conferences, these years refers to materials where conference proceedings were available.

2 The keyword density refers to the number of times a keyword appears on a given piece of text or content as a ratio or percentage of the overall world count.

3 For example, the actual times the term "development" is mentioned as a stand-alone concept is derived by subtracting the number of times it appears as a two-word concept ["sustainable development" or "urban development"] from the total number of times the word "development" exists in a text.
} 
that were significant in some years but not others but were related to a broader theme were reclassified under the more generic codes. For instance, in 1996, the terms referencing "teaching" and "learning" were significant in titles that were presented during that year but were less prominent in others. As such, those terms were recoded under the 'education' theme. In addition, terms such as 'city' and 'urban' that referenced similar themes of urbanization were recoded under the 'urban' theme. The final results are presented in Annex A and the major findings are discussed in the next section.

\section{Key Themes over the Years}

\section{The Formative Years: 1990 - 1999}

SEAGA was first established in 1990 as a regional network for members to "share interests in the theory, methods, and practice of geography and geographic education" (Southeast Asian Geography Association, 2008). In its incipient years, the variety of topics discussed were modest by contemporary standards. Three main themes were deliberated at the first conference in 1990: i) Geography education; ii) Environment and resources, and iii) Socioeconomic issues. Similarly, our data show that the terms 'development', 'geography education' and 'environment' were the most frequent concepts to appear in 1990.

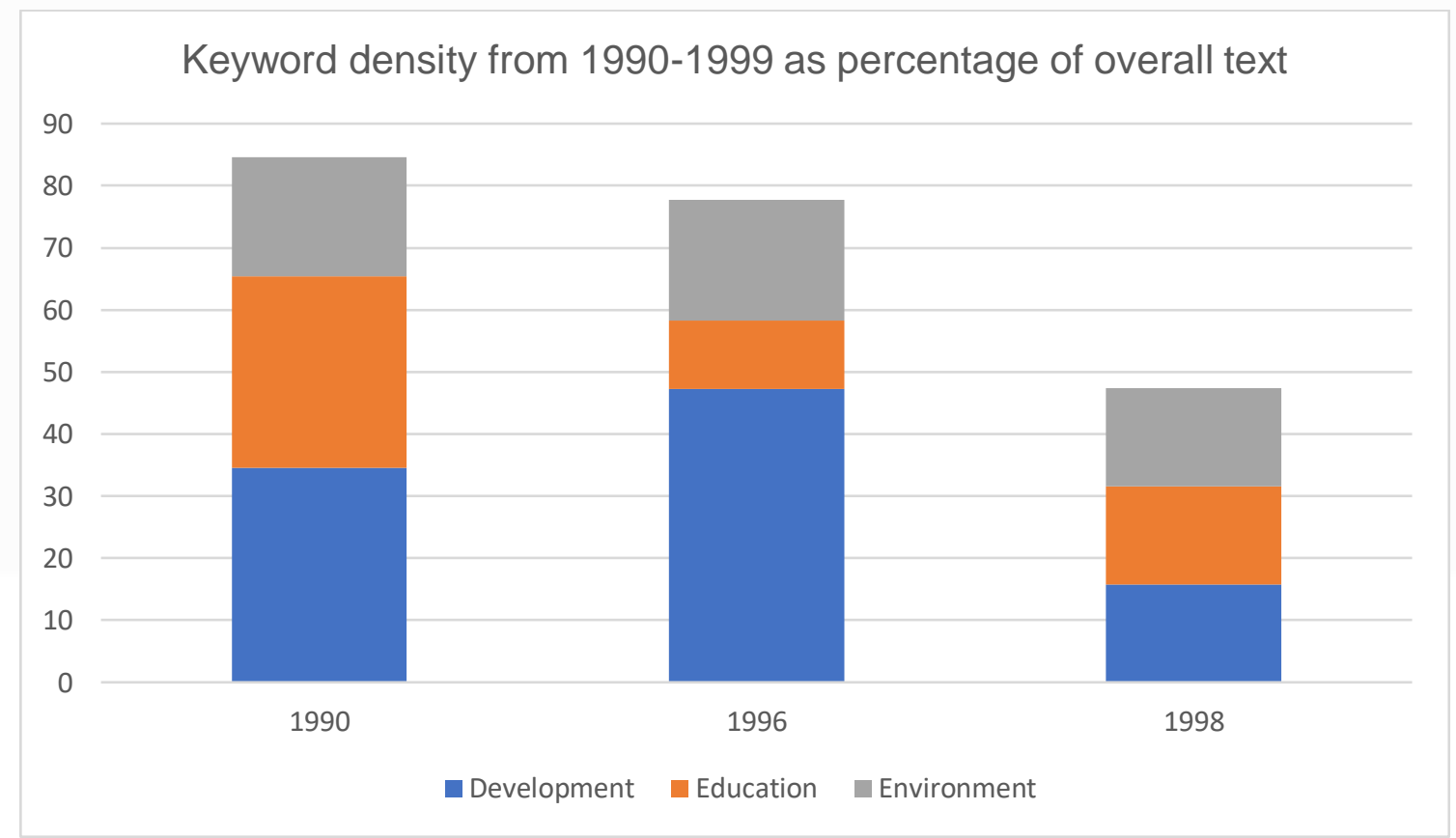

Figure 1. Keyword Density of Terms for SEAGA Conferences from 1990-1999

Tracing the historical trajectory of these terms in 1990, 1996, and 1998, Figure 1 shows that while the topic of development grew in prominence from 1990 to 1996, it sharply declined in 1998. Conversely, while there was a panel for 'geographic education' at the 1996 conference, only four out of ten papers presented dealt with 
themes of education. The low number of education papers at this point could ${ }^{4}$ be due to the fact that scholarship on geography education (International Geographic Union - Commission on Geographical Education, 1992) in the Southeast Asian region was still at its aspirational stage. The remaining papers in the panel focused on a range of issues including sustainable development, public policy, and thematic mapping. There was, however, a slight resurgence in topics of education from 1996 to 1998. These trends can be attributed to the conference themes of a given year. Given that the theme of the 1996 SEAGA conference was "Geography and the development of the Southeast Asian region", there was an increase in the submissions on topics of development. Similarly, the resurgence in the topic of education and the relative reduction in the papers on development and the environment in 1998 can be partly attributed to the overarching theme of the conference - "Geography and Geographic education in the $21^{\text {st }}$ century". As such, the topics featured in each conference closely parallels the theme of the conference.

\section{From Development to Sustainable Development: 2000 - 2009}

The first decade of the $21^{\text {st }}$ century heralded a shift toward more crossdisciplinary topics in SEAGA conferences. Specifically, the $8^{\text {th }}$ SEAGA conference in 2006 refocused academic discourses from development to sustainable development (Tan \& Chang, 2008), inviting trans-disciplinary perspectives of sustainability from scholars, policymakers, researchers, entrepreneurs, and teachers. This growing emphasis on sustainability parallels the wider trends in academia and policymaking following the Millennium Development Goals and the Johannesburg Declaration on Sustainable Development and the Plan of Implementation, adopted at the World Summit on Sustainable Development in 2002 (UNESCO, 2015). In fact, the concept of sustainability was popularized in 2006 with the conference theme "Sustainability and Southeast Asia" - and our data shows that the terms 'sustainability' and 'sustainable development' had the highest keyword density of 20.5 and 16.1 percent in that year (See Figure 2 and Annex A).

\footnotetext{
4 The number of education themed presentations was higher in 1990 than in 1996 because of seven country papers that featured background information on the education systems of seven Asian localities including Singapore, Thailand, Brunei, Indonesia, Malaysia, Philippines, and Hong Kong. These papers were relatively rudimentary in terms of the scope of the education systems in these localities. In comparison, the 1996 papers on education and the subsequent years featured a deeper theoretical coverage of the topic.
} 
Keyword density from 2000-2009 as percentage of overall text

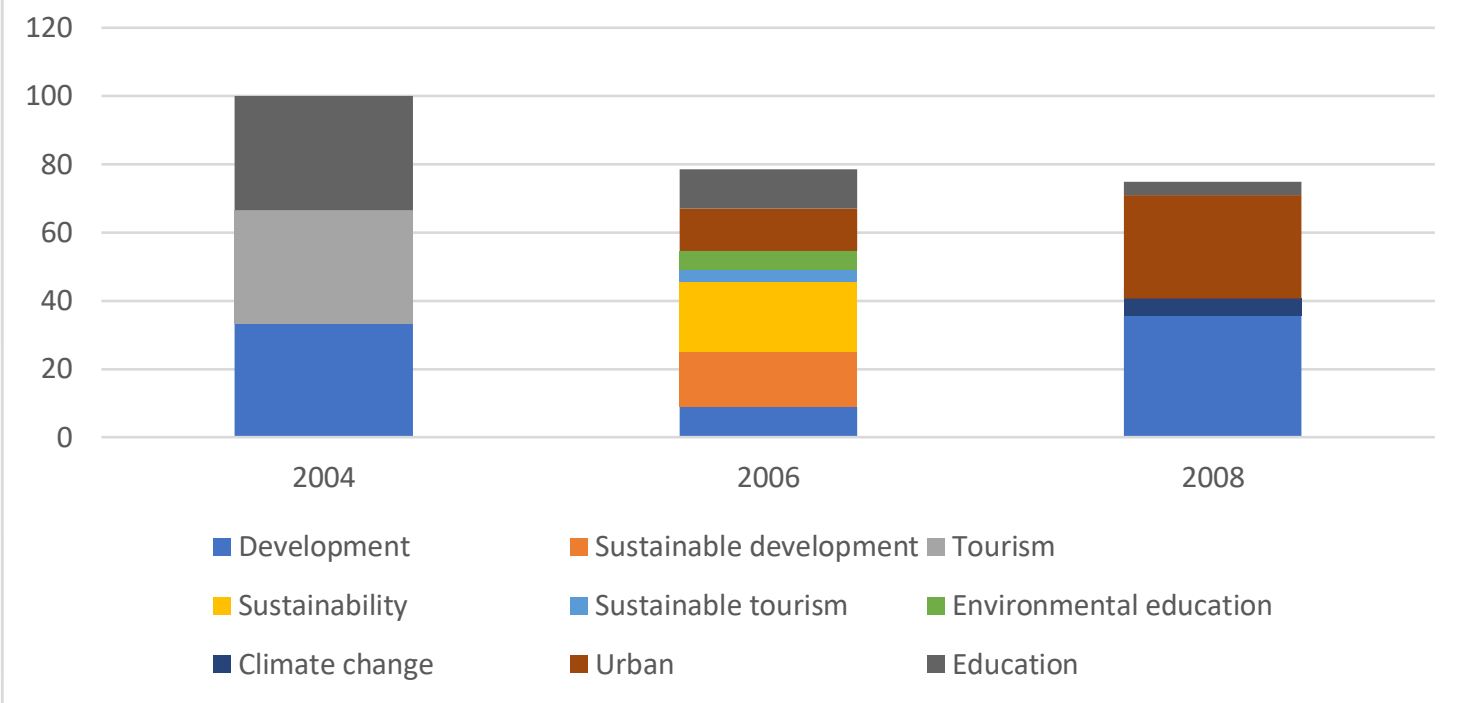

Figure 1. Keyword Density of Terms for SEAGA Conferences from 2000-2009

Aside from sustainable development, our findings also suggest an increasing variation of topics presented in SEAGA conferences in the late 2000s. As Figure 2 shows, while topics involving development, tourism, and education were some of the commonly presented topics in the 2004 conference, these three terms declined between 2006 and 2008. This, however, does not signify the depreciating influence of these topics. Rather, it represents the diversification of knowledge and expertise within the various sub-fields as evident in our data (as shown in Figure 2 and Annex A) that points to the prevalence of topics such as climate change, urbanization, and sustainable development in the late 2000s. Moreover, given the conference theme in 2006, there was a discernible increase in the discourse on geographical and environmental education as evidenced by the presence of two distinct panels on education and sustainability in that year. In fact, selected presentations were then included in a special issue in the Journal "International Research in Geographical and Environmental Education" in 2008. The conversation between geography and geography education academics has never stopped through this decade. In many ways, the increasing variation of topics in our data attests to the positive trend of more analytical and comprehensive discourses shaping SEAGA conferences in recent years.

\section{The Contemporary Era: 2010 - 2017}

In the recent decade, despite the persistence of development topics in SEAGA conferences, issues of climate change, sustainable development, and urbanization have become increasingly prominent. As indicated in Figure 3 and the data in Annex A, the keyword density for topics on development and environmental issues were relatively high in 2010 with each term gathering 19.1 and 21.3 per cent respectively. Correspondingly, while topics on climate change and development garnered greater coverage in 2012 and 2014 respectively, there was a slump on both topics in 2017. 
Chang, C. H. \& Singh, S.A. (2021). Developments in academic geography and its relationship with...

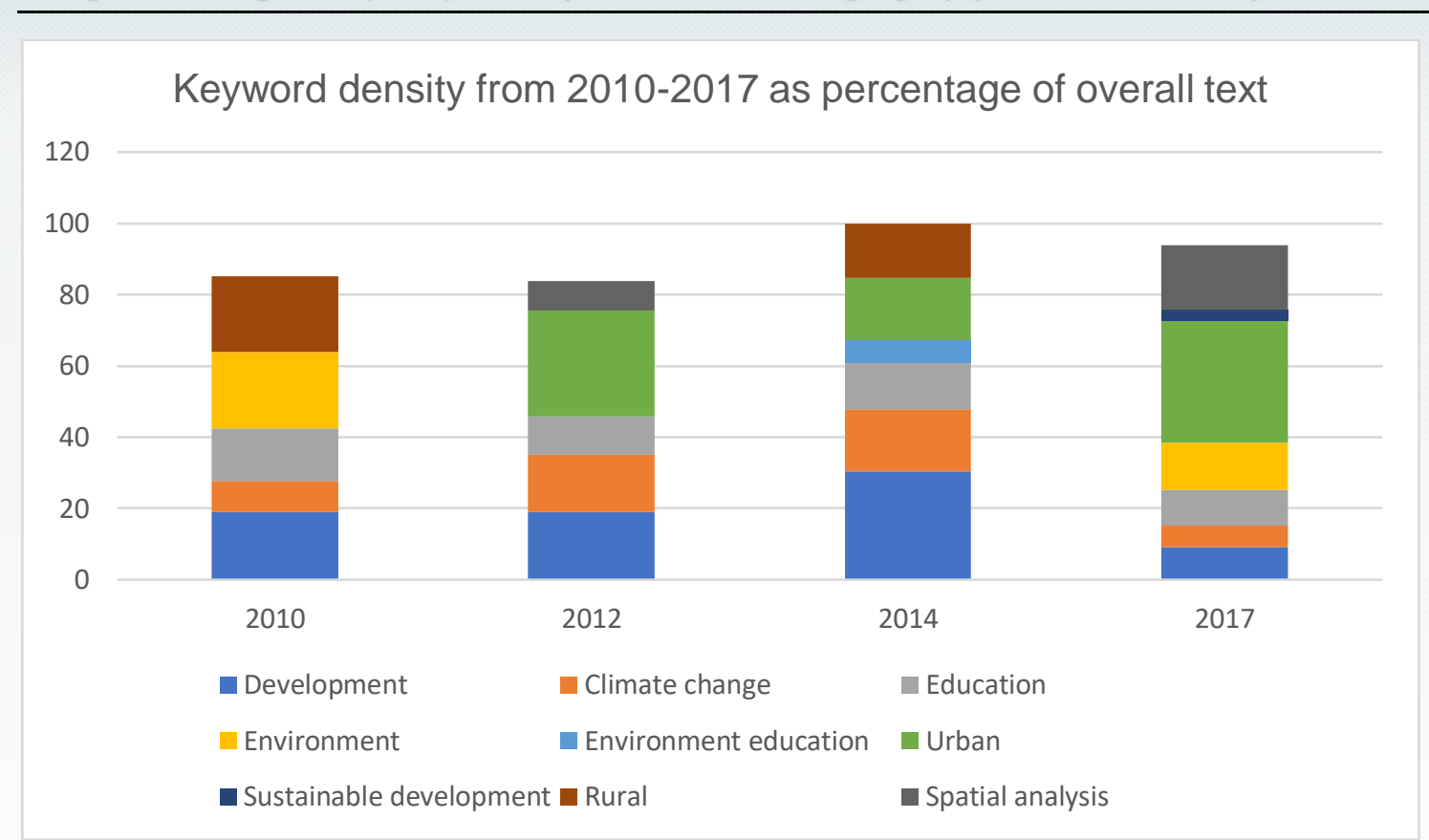

Figure 2. Keyword Density of Terms for SEAGA Conferences from 2010-2017

While urbanization has received regular coverage since 2012, the data in Figure 3 and Annex A reveals that rural topics have been infrequent in SEAGA proceedings. Rural titles were prominently featured in 2010 and 2014, but presentations on the topic in 2012 and 2017 were sparse. However, this trend more likely points to the interdisciplinary nature of the topic as issues of rural concern have been discussed under physical geography or sustainability. On the other hand, the discourse on education has been consistent throughout this decade. Between 2010 and 2017, coverage on education topics have fluctuated between its highest level in 2010 at 14.9 percent and its lowest at 10.1 percent in 2017. In 2014 and 2017, there have been at least two panels on geography education. Although stable, the minor depreciation in 2017 is likely a result of the expanding number of overall titles in SEAGA conferences presented between 2010 and 2017. In fact, the number of titles presented have increased by more than 50 percent between 2010 and 2017 . As such, despite the relatively consistent number of education topics presented, the figures show a slight decline in terms of the overall percentage. Moreover, given the increasing sophistication of education themed titles presented in SEAGA conferences recently, it could be posited that we are in a maturation phase of Southeast Asia where there are pockets of excellence in geographical, environmental, and sustainability education (Chang et al., 2019; International Geographic Union - Commission on Geographical Education, 2016). Our analysis also revealed a concomitant proliferation of other topics such as urbanization, spatial patterns, and sustainability. The following section will provide a general discussion of the key trends and challenges facing SEAGA conferences over the years and its implication for school geography. 


\section{Discussion}

The evolution of Geography in the Southeast Asian context has, in large part, been abetted by a strong network of academics and universities from around the region that have undertaken the responsibility of hosting the biennial SEAGA conferences since 1990 (Ooi \& Goh, 2008, p. 295). While there have been many positive developments that have enhanced research findings and stimulated a greater interest into less-researched fields, there are still gaps in the field of Southeast Asian Geography that can be further investigated. Geography education is always one of the key themes throughout the three periods of analysis. Indeed, one can argue that the academic geography community in Southeast Asia has always looked to being involved in the discussion on topics of geography education. Notwithstanding this fact, topics in academic geography have also changed through the three periods and this has certain impact on the school geography curricula in countries of the region. Considering the diversity of education systems and curricula throughout the region alongside the competing influences of local and provincial governments over curriculum policies, gathering a holistic understanding of the changes to geography curricula across the region is beyond the scope of this paper. Rather, the authors will focus on significant periods in time. While the authors do not seek to provide a comprehensive account of the underlying factors and mechanisms that influence the dominance of specific themes over others, the argument is that there has been a politicization ${ }^{5}$ of geography that has served the interests of significant power groups (Marsden, 1989). We acknowledge that in few instances, the rise of certain themes could be a result of disciplinary shifts that are independent from external forms of politicization. Nonetheless, we contend that it is hard to distinguish disciplinary shifts from politicization as discursive shifts within the discipline could also be regarded as a form of politics. Politicization, in other words, is not merely limited to unforeseen political circumstances or lobbying by interest groups, but also includes academic discourse and its corresponding effects on the discipline. In this regard, the authors will highlight key periods that have precipitated a change in geography curricula in Singapore to better understand the effects of academic discourse in school curricula. Moreover, when considering the changing number of presentations over time and how the conference has evolved, the authors are not necessarily comparing like with like each year. Indeed, how conference themes are decided will have an impact on the focus of the presentations. The authors will also discuss some of the positive trends and address some gaps in the field of Southeast Asian geography.

\section{Diversification of Research Within and Across Themes and Topics}

While our data suggest that there has been a decline in topics addressing the keywords of development, education, and the environment, it does not imply a corresponding reduction in the interest of research on these topics. Rather, the

${ }^{5}$ According to Marsden (1989), politicisation refers to the use of the "curriculum and informal channels of education to serve the ends of significant power groups, whether the church, the state, or some other body, even the 'education establishment', so that explicitly or implicitly employed techniques of inculcation, indoctrination, and loaded selection of material, dictate the content, values, attitudes, and beliefs to be transmitted". 
proliferation of alternative keywords pertaining to these themes such as climate change, environmental education, sustainable development, and urbanization in recent years suggests a deepening of research within these themes. In fact, since 1990 SEAGA conferences have seen a growing pattern of presentations undertaking cross-thematic studies including the role of development on the environment and society, the impact of specialization on the environment and development, and the role of education in managing challenges such as climate change and globalization. The increasing trend of cross-thematic research represents the expanding capacities and skills of researchers, academics, and educators across the region to challenge traditional boundaries of knowledge and appreciate the complexity of linkages and relationships between multiple variables driving social phenomena in the region. Moreover, invoking Marsden's (1989, p. 509) framework on politicization, these cross-thematic studies are also a product of a growing international initiative toward multi-disciplinary learning in academia. Universities and higher education institutions in Southeast Asia have been gradually embracing the multi-disciplinary model in an effort to cultivate twenty-first century competencies such as critical thinking and inquiry among its students (International Commission on Education for the Twenty-first Century, 1996). Academic research in geography in Southeast Asia, therefore, has gradually embraced cross-thematic studies over the past three decades.

Despite these positive advancements, there have been certain themes and topics that have been understudied. For instance, presentations involving geopolitics and political geography have been rare. Given the abundance of political conflicts involving geographical boundaries, immigration, and environmental degradation within Southeast Asia (e.g. the situation faced by the Rohingyas in Myanmar, the trans-boundary pollution caused by deforestation in Indonesia, and the impact of development on the 'stateless' peoples of Zomia), there are multiple opportunities for further research in this field. The scarcity of these topics in SEAGA proceedings despite the severity of these issues in the region could be attributed to the absence of a significant group or agent in incentivizing research in these topics. While these issues have been widely covered in the disciplines of Sociology, Political Science, and International Relations which traditionally utilize economic, political, and social paradigms, a geographical perspective can advance a more comprehensive understanding of these phenomena by also looking at the biophysical and cultural paradigms (National Research Council, 1997). Additionally, Geography offers the enduring dimension of spatial scales, from the global to the highly local. This optimizes the examination of multiple controlling mechanisms across spatial, and even temporal scales (National Research Council, 1997).

\section{Increased Emphasis on Sustainability and the Environment}

As figure 4 shows, while conference themes in the 1990s have hovered between general themes of development and the Southeast Asian region, the recent themes in 2014 and 2017 have been focusing on sustainability and the environment. This trend is not just peculiar to Southeast Asian Geography but is also observed in the broader field of the Social Sciences. 


\begin{tabular}{|c|c|}
\hline Year & Conference Theme \\
\hline 1990 & Conference on Geography in the ASEAN Region \\
\hline 1996 & Geography and The Development of the Southeast Asia Region \\
\hline 1998 & Geography and Geographic Education in the $21^{\text {st }}$ Century \\
\hline 2004 & Development and Change in an era of Globalisation \\
\hline 2006 & Sustainability and Southeast Asia \\
\hline 2008 & $\begin{array}{l}\text { Transformations and Embodiments in Southeast Asian Geographies: } \\
\text { Changing Environments, People and Cultural Groups, Institutions and } \\
\text { Landscapes }\end{array}$ \\
\hline 2010 & Understanding the changing space, place and cultures of Asia \\
\hline 2012 & Whose Geography? Space, place and cultures of Asia \\
\hline 2014 & $\begin{array}{l}\text { Geography that matters: Unravelling the destiny for environment, } \\
\text { society and people in Asia }\end{array}$ \\
\hline 2017 & $\begin{array}{l}\text { Geography for global understanding: Sustainable changes in } \\
\text { environment, society and people }\end{array}$ \\
\hline
\end{tabular}

Figure 3. Conference themes from 1990 to 2017

It could be argued that this newfound interest is a spillover from the increased international recognition towards climate change issues. In 2013, the United Nations Intergovernmental Panel on Climate Change (IPCC) released a comprehensive report affirming the role of human activities on climate change (Intergovernmental Panel on Climate Change, 2013). The report represented a milestone in climate change policy as governments around the world spun into action to deliberate a new framework to curb greenhouse gas emissions. This international collaboration resulted in the conception of the Paris Agreement in 2015 - a series of measures aimed at limiting rising temperatures to 1.5 degrees Celsius (United Nations Climate Change, 2015). With increased attention toward climate change issues at the international level, more interest and resources have also been allocated to these concerns at the national and regional levels. Moreover, the rapid industrialization of the region has fomented environmental concerns that transcend national boundaries. Deforestation and slash-and-burn agriculture in Indonesia, for instance, have led to the transboundary haze pollution in nearby Singapore and Malaysia, affecting the health of millions and lost productivity in the region. As such, issues of sustainability and climate change will be a primary focus for SEAGA as evidenced by the theme of the forthcoming SEAGA conference in 2021 - "Opportunities and challenges for Sustainability in the 2020s: Understanding environments, societies and identities in Southeast Asia".

\section{Broader Implications on A Global Scale and in School Curricula}

These developments in academic geography in the Southeast Asian region are not too different from the discourses in other parts of the world. Cresswell (2013) and Rawding (2010) have outlined the evolution of geographical paradigms over the 
course of history in North America and Europe. For instance, Rawding (2010) highlights the prominence of regional approaches in the 1950s and early 1960s which was succeeded by the positivist approaches during the "quantitative revolution" of the late 1960s and early 1970s (Billinge, Gregory, \& Martin, 1984). The subsequent paradigmatic shifts toward Humanistic, Marxist, Feminist, Postmodernist, and Poststructuralist geographies were responses to the inadequacies of the positivist approach (Rawding, 2010).

Likewise, Cresswell's (2013) analysis of the evolution of the discipline is similar to Rawding's (2010). Cresswell (2013), however, extends this analysis by detailing the theoretical frameworks underpinning these paradigms. For example, he notes that the eminence of regionalism as an approach in the discipline during the 1950s and early 1960s was a product of essentialist epistemologies that regarded knowledge of a social group or region as defined by an "objective reality" (Cresswell, 2013 , p. 174). Not only were these essentialist worldviews common in academia in the decades of the 1950s and 1960s (Cresswell, 2013; Whittlesey, 1954), but were dominant in the analysis of policymakers and educators in schools and curriculum planning (Alatas, 1977; Said, 1978).

This was evidenced in a previous work by Chang (2014) that highlights the close alignment between geography curricula in schools and the shifting discourses in academic geography in Singapore. In general, the evolution of the geography curriculum in Singapore could be characterized as a "slow waltz" between three main approaches: i) regional studies, ii) systematic geography, and iii) thematic geography. From 1959 to the early 1970s in Singapore, the geography curriculum was " organized by locational and descriptive information about places and human activities through a regional lens" (Chang, 2014, p. 29). This approach was eventually replaced by a systematic geography syllabus in 1983 which was reorganized around concepts such as location, direction, scale, and environment while grounded in the Singaporean context (Chang, 2014). By the 2000s, the syllabus was further overhauled to a more conceptual approach with a greater attention toward human-environmental and spatial relationships (Chang, 2014). This trend parallels the broader thematic transitions in SEAGA conferences and suggests the significance of networks of influence between scholars and curriculum planners that should be further studied. As far as Singapore is concerned, we contend that significant power groups that include the Ministry of Education (MOE) was a key actor in driving curricular changes in geography in Singapore schools, as a response to social and cultural concerns. As observed by Chang (2012) in his analysis of the state of school geography in Singapore in the early 2010 s, there have been an increased curricular emphasis on environmental management and other themes related to the environment. The topic of global warming, for instance, was included in the grade 8 syllabus from 2001 until 2012, and it was not until 2013 that the topic was taught at grade 9 (Chang, 2012). This trend coincides with the increasing emphasis and pluralization of environmental topics in SEAGA conferences in the 2000s. It was also due to efforts by the National Climate Change Secretariat (NCCS) which worked closely with the MOE's Curriculum Planning Design and Development unit to ensure that the topic was endowed with sufficient coverage. Therefore, this underscores the 'slow waltz' between the changing 
discourses in academic geography and the curricular changes in geography education (Chang, 2014).

\section{References}

Alatas, S. H. (1977). The Myth of the Lazy Native: A Study of the Image of the Malays, Filipinos and Javanese from the 16th to the 20th Century and Its Function in the Ideology of Colonial Capitalism. London: Routledge.

Billinge, M., Gregory, D., \& Martin, R. (1984). Recollections of a revolution: geography as spatial science. London: Macmillan.

Chang, C.-H. (2012). The changing climate of teaching and learning school geography: the case of Singapore. International research in geographical and environmental education, 21(4), 283-295. doi:10.1080/10382046.2012.725965

Chang, C.-H. (2014). Is Singapore's school geography becoming too responsive to the changing needs of society? International research in geographical and environmental education, 23(1), 25-39. doi:10.1080/10382046.2013.858405

Chang, C.-H., Simmons, B., Braus, J., Kidman, G., Mochizuki, Y., Burkhardt-Holm, P.; Matakupan, S. (2019). The Singapore Declaration on Research in Education for Sustainable Development. Retrieved from Singapore:

Cresswell, T. (2013). Geographic thought: a critical introduction. Chichester, West Sussex, UK Wiley-Blackwell.

International Commission on Education for the Twenty-first Century. (1996). Learning: the treasure within; report to UNESCO of the International Commission on Education for the Twenty-first Century. Retrieved from Paris, France:

International Geographic Union - Commission on Geographical Education. (1992). International Charter on Geographic Education. Retrieved from

International Geographic Union - Commission on Geographical Education. (2016). International Charter on Geographical Education. Retrieved from http://www.igucge.org/2016-charter/

Marsden, W. E. (1989). All in a good cause: Geography, history and the politicization of the curriculum in nineteenth and twentieth century England. Journal of Curriculum Studies, 21(6), 509-526.

National Research Council, C. o. G., Environment, and Resources,. (1997). Rediscovering geography : new relevance for science and society (0309051991). Retrieved from https://login.libproxy.nie.edu.sg/login?url=https://search.ebscohost.com/login.asp $\mathrm{x}$ ?direct=true $\& \mathrm{db}=$ cat04502a $\& A N=$ nie.177372\&site=eds-live $\&$ scope=site

Ooi, G. L., \& Goh, K. C. (2008). Networking for the Region and Beyond - Role of the Southeast Asian Geography Association (SEAGA). International Research in Geographical and Environmental Education, 17(4), 292-297.

Rawding, C. (2010). What are the connections between subject developments in academic and school geography? International research in geographical and environmental education, 19(2), 119-125. doi:10.1080/10382046.2010.482198

Said, E. W. (1978). Orientalism. New York: Pantheon Books. 
Chang, C. H. \& Singh, S.A. (2021). Developments in academic geography and its relationship with...

Shamsul, A. B. (2007). Producing Knowledge of Southeast Asia: A Malaysian View. Journal of Inter-Asia Cultural Studies (Special Issue), 118-138.

Southeast Asian Geography Association. (2008). Welcome Address to SEAGA. Retrieved from https://www.seaga.info/

Taiwo, O. (1993). Colonialism and Its Aftermath: The Crisis of Knowledge Production. Callaloo, 16(4), 891-908. doi:10.2307/2932216

Tan, I. C., \& Chang, C.-H. (2008). Geography Education for Sustainable Development in Southeast Asia. International Research in Geographical \& Environmental Education, 17(4), 289-291. doi:10.1080/10382040802401490

UNESCO. (2015). The Sustainable Development Goals. Retrieved from https://www.un.org/sustainabledevelopment/development-agenda/

Whittlesey, D. (1954). The regional concept and the regional method. In P. James \& C. F. Jones (Eds.), American Geography: Inventory and Prospect (pp. 19-68). Syracuse, NY: Syracuse University Press.

wizdom.ai. (2019). Journal of Geography: Content. Retrieved from https://www.wizdom.ai/journal/journal_of_geography/content/0022-1341

Woube, M. (1999). Conference Report: 5th Southeast Asian Geography Conference on Geography and Geographic Education in the 21st Century. The Geographic Journal, 165(2), 243.

\section{Biographical Statements}

Chew-Hung CHANG is an Associate Professor at the National Institute of Education, Nanyang Technological University, Singapore. His research interest includes geography education, curriculum and teaching and climate change education.

Shyam Anand SINGH is a research assistant at the National Institute of Education, Nanyang Technological University, Singapore.

\section{Annex A}

\section{Keyword Density of Terms in SEAGA Conferences from 1990-2017}

\begin{tabular}{|l|l|l|}
\hline Keyword Density & No. of times & $\%$ \\
\hline 1990 & & \\
\hline Development & 9 & 34.6 \\
\hline Education & 8 & 30.8 \\
\hline Environment & 5 & 19.2 \\
\hline Resources & 4 & 15.4 \\
\hline Total & 26 & \\
\hline & & \\
\hline 1996 & & \\
\hline Development & 17 & 47.2 \\
\hline Environment & 7 & 19.4 \\
\hline Spatial & 5 & 13.9 \\
\hline
\end{tabular}


(C) RIGEO $\bigcirc$ Review of International Geographical Education

11(3), Summer 2021

\begin{tabular}{|c|c|c|}
\hline Education & 4 & 11.1 \\
\hline Remote sensing & 3 & 8.3 \\
\hline Total & 36 & \\
\hline \multicolumn{3}{|l|}{1998} \\
\hline Land & 4 & 21.1 \\
\hline Geomorphology & 3 & 15.8 \\
\hline Environment & 3 & 15.8 \\
\hline Coastal & 3 & 15.8 \\
\hline Development & 3 & 15.8 \\
\hline Education & 3 & 15.8 \\
\hline Total & 19 & \\
\hline \multicolumn{3}{|l|}{2004} \\
\hline Development & 3 & 33.3 \\
\hline Tourism & 3 & 33.3 \\
\hline Education & 3 & 33.3 \\
\hline Total & 9 & \\
\hline \multicolumn{3}{|l|}{2006} \\
\hline Sustainability & 23 & 20.5 \\
\hline Development & 10 & 8.9 \\
\hline Education & 13 & 11.6 \\
\hline Urban & 14 & 12.5 \\
\hline Environment & 7 & 6.25 \\
\hline Land & 12 & 10.7 \\
\hline Sustainable development & 18 & 16.1 \\
\hline Environmental education & 6 & 5.4 \\
\hline Natural resource & 5 & 4.5 \\
\hline Sustainable tourism & 4 & 3.6 \\
\hline Total & 112 & \\
\hline \multicolumn{3}{|l|}{2008} \\
\hline Development & 27 & 35.5 \\
\hline Urban & 23 & 30.3 \\
\hline Land & 10 & 13.2 \\
\hline Environment & 10 & 13.2 \\
\hline Education & 3 & 3.9 \\
\hline Climate change & 3 & 3.9 \\
\hline Total & 76 & \\
\hline \multicolumn{3}{|l|}{2010} \\
\hline Environment & 10 & 21.3 \\
\hline
\end{tabular}


Chang, C. H. \& Singh, S.A. (2021). Developments in academic geography and its relationship with...

\begin{tabular}{|l|l|l|}
\hline Rural & 10 & 21.3 \\
\hline Development & 9 & 19.1 \\
\hline Education & 7 & 14.9 \\
\hline Land & 7 & 14.9 \\
\hline Climate change & 4 & 8.5 \\
\hline Total & 47 & \\
\hline & & \\
\hline 2012 & & \\
\hline Urban & 11 & 29.7 \\
\hline Development & 7 & 18.9 \\
\hline Land & 6 & 16.2 \\
\hline Education & 4 & 10.8 \\
\hline Climate change & 6 & 16.2 \\
\hline Spatial analysis & 3 & 8.1 \\
\hline Total & 37 & \\
\hline & & \\
\hline 2014 & & \\
\hline Development & 14 & 30.4 \\
\hline Urban & 8 & 17.4 \\
\hline Rural & 7 & 15.2 \\
\hline Education & 6 & 13 \\
\hline Climate change & 8 & 17.4 \\
\hline Environment education & 3 & 6.5 \\
\hline Total & 46 & \\
\hline & & \\
\hline 2017 & & \\
\hline Urban & 34 & 34.3 \\
\hline Environment & 13 & 13.1 \\
\hline Education & 10 & 10.1 \\
\hline Development & 9 & 9.1 \\
\hline Sustainability & 6 & 6.1 \\
\hline Spatial analysis & 18 & 18.2 \\
\hline Climate change & 6 & 6.1 \\
\hline Sustainable development & 3 & 3 \\
\hline Total & 99 & \\
\hline & & \\
\hline & & \\
\hline & & \\
\hline & & \\
\hline & & \\
\hline
\end{tabular}

